\title{
HIPERTROFIA DO SUPREMO TRIBUNAL FEDERAL À LUZ DO PODER
}

\author{
MODERADOR
}

Ivan Luduvice Cunha ${ }^{1}$

Ricardo Pereira Pérez ${ }^{2}$

\begin{abstract}
Resumo: A atuação do Supremo Tribunal Federal tem sido sucessivamente evidente na mídia e provocado inúmeras críticas, resultando no descrédito do Supremo Tribunal Federal. Além disso, tem-se questionado os limites da competência do Supremo, que tem agido como "poder moderador". Todavia, o Poder Moderador era tido como um poder efetivo, objetivo e equilibrado. No presente artigo, por meio da pesquisa bibliográfica e do método indutivo, abordar-se-á o fundamento histórico do quarto poder e como este fora desvirtuado ao longo dos anos pela Corte Brasileira.
\end{abstract}

Palavras-chave: Supremo Tribunal Federal. Poder Moderador. Descrédito do Judiciário. Separação de Poderes. Freios e Contrapesos.

\section{HYPERTROPHY OF THE SUPREME FEDERAL COURT IN THE LIGHT OF MODERATING POWER}

\begin{abstract}
The performance of the Federal Supreme Court has been successively evident in the media, and it has provoked innumerable criticisms, resulting in the discredit of the Supreme Court. In addition, the limits of the competence of the Supreme Court, which has acted as a "moderating power", have been questioned. However, the Moderating Power was seen as an effective, objective and balanced power. In this article, through bibliographic research and the inductive method, the historical basis of the fourth power will be addressed and how it has been distorted over the years by the Brazilian Court.
\end{abstract}

\footnotetext{
${ }^{1}$ Doutorando em Direito na Escola Superior Dom Helder Câmara, mestre em Direito pela Faculdade de Direito Milton Campos, especialização em Direito Público pelo Centro Universitário Salesiano de São Paulo e graduação em Direito pela Universidade Católica de Santos. $1^{\circ}$ vice-presidente da Associação Nacional dos Procuradores dos Estados e do Distrito Federal e conselheiro da Ordem dos Advogados do Brasil - Seccional de Minas Gerais. Presidente da Associação dos Procuradores do Estado de Minas Gerais por dois mandatos (2016/2018 e 2018/2020). Procurador do Estado de Minas Gerais. ORCID: https://orcid.org/0000-0002-82858697

${ }^{2}$ Mestrando em Direito pela Universidade FUMEC e graduação em Direito pela Universidade Federal de Minas Gerais. Procurador do Município de Belo Horizonte. ORCID: https://orcid.org/0000-0002-7102-8567
} 
Keywords: Federal Supreme Court. Moderating Power. Judicial Discredit. Separation of Powers. Brakes and Counterweights.

\section{INTRODUÇÃO}

$\mathrm{Na}$ última década tornou-se cada vez mais comum a divulgação de notícias relacionadas ao Poder Judiciário, mais especificamente, sobre a Suprema Corte Brasileira. Após a promulgação da Constituição de 1988 a Corte passou a contar com mais autonomia e independência, bem como com competências exorbitantemente ampliadas e hipertrofiadas.

Todavia, malgrado essa atuação do Supremo tenha trazido alguns avanços no que diz respeito ao desenvolvimento de alguns direitos fundamentais, ela tem provocado inúmeras críticas. E uma delas, seria se o Supremo detém competência para agir como o novo poder moderador.

Ao se fazer uma análise do pensamento político brasileiro, nota-se que o poder moderador inicialmente proposto assumiu na contemporaneidade formas desfiguradas das propostas pensadas pelos primeiros pensadores em sua concepção original, uma vez que o exercício do executivo e do próprio poder moderador têm sido atribuídos a uma só entidade, sendo que a proposta inicial era justamente separar esses poderes para um melhor funcionamento do parlamentarismo.

Ao se falar em Poder Moderador, buscava-se o equilíbrio de Estado, isto é, um poder que fosse capaz de equilibrar as tensões comuns do exercício do poder em relação a própria fonte do poder, e consequentemente, mantivesse a independência e a atuação autônoma de cada poder.

Autores como Borges de Menezes defendem a atuação do presidente como Poder Moderador. Ocorre que para entender essa conceituação, faz-se necessário considerar o Poder Moderador como uma forma em constante evolução, diferente da sua forma tradicional no Poder Imperial, que contava com uma estrutura que muitas vezes se confundia com a própria forma absolutista de poder, e por isso, incompatível com um Estado democrático moderno.

Todavia, o Poder Moderador não pode se limitar ao estudo de apenas um elemento, como "Guardião da Constituição" ou "Poder do Poder". Ao contrário, deve-se considerar esse poder como um poder efetivo, objetivo e equilibrado, embasado em uma teoria sólida e 
fundamentada. Assim, mister se faz a definição de um conceito para que se faça possível o entendimento de como a ação do Poder Moderador existente na Constituição de 1824 pode (ou não) ser aplicado no Estado Brasileiro atual.

A metodologia utilizada será o tipo bibliográfico e documental, baseada em fundamentação teórica específica, visto que a formação do Poder Moderador é em um primeiro momento uma ação teórica, visando à formação em essência do Estado.

\section{O PODER MODERADOR}

O Poder Moderador foi concebido por Benjamin Constant (1989), autor liberal suíço, que propôs uma teoria constitucional de limitação de poder, como um mecanismo de controle entre os poderes: a criação de um quarto poder, dotado das características de neutralidade, potencial equilibrador. Constant estipulou a separação entre o poder do rei e o poder do governo, assim como a divisão do Poder Legislativo em duas câmaras (poder representativo de continuidade e poder representativo de opinião). O rei, necessariamente desligado dos interesses dos demais Poderes, exerceria o Poder Moderador sobre as duas câmaras, os ministros (exercentes do poder de governo) e os juízes. O autor considerava que seria necessária a delegação do poder soberano aos governantes. (CONSTANT, 1989).

A remissão à ideia de Constant no contexto jurídico-político brasileiro pode evocar uma imagem indesejável, dado que "no Brasil, mais uma vez a importação de um instituto não funcionou em nossa engrenagem político-jurídica, tendo o Imperador simplesmente deixado de ser neutro ao amesquinhar os demais poderes com sua força” (BESTER, 2005).

O Poder Moderador era exercido pelo Imperador, cujo título era "imperador constitucional e defensor perpétuo do Brasil", recebendo o tratamento de "Majestade Imperial”. O art. 99 da Constituição do Império (BRASIL, 1924) afirmava que a pessoa do Imperador era inviolável e sagrada, e não estava sujeita à responsabilidade alguma. O Poder Moderador era um poder autoritário disfarçado de solução para todos os problemas, cujo detentor atuava somente em causa própria, embora seu discurso remetesse ao bem comum.

Ocorre que na prática, o titular do quarto Poder exercia um tipo de controle arbitrário sobre os demais Poderes e violava a separação de Poderes nos moldes propostos por Montesquieu. Além disso, o quarto Poder, ao possuir a ampla competência de intervenção nos 
demais Poderes, desestabilizava o sistema de freios e contrapesos no intuito de possibilitar a coexistência dos Poderes. (PAZZINATO; SENISE, 2002).

Segundo Constant, Executivo, Legislativo e Judiciário "são três engrenagens que devem cooperar, cada qual em seu âmbito, com o movimento geral" (CONSTANT, 2005, p.19), Para o autor, uma Instituição que concentrasse tanto a faculdade de impedir quanto a de agir em um único órgão poderia ser mais danoso que a mera concentração da primeira em um único centro. Na mesma linha de Constant, atualmente pode-se fazer críticas à atividade judiciária do Supremo Tribunal Federal, que, sob diversos pretextos, imiscui-se no Executivo e no Legislativo e amplia sua competência para além dos ditames constitucionais, inclusive em âmbito criminal.

Todavia, impende destacar que autores como Borges de Medeiros, na sua obra intitulada: O poder moderador na república presidencial de 1933, (MEDEIROS, 2002), defende o poder moderador com uma perspectiva de correção pela sua própria concepção original, observando o aperfeiçoamento do sistema presidencialista. Medeiros (2002) supervalorizava a figura do presidente eleito pelo povo como primeiro representante e peça fundamental no processo democrático.

Assim, sobre os mecanismos que permitem a destituição do depositário do poder moderador, o autor aduz que o presidente "poderá ser submetido a um plebiscito, mediante dois terços dos votos dos membros da assembleia. No entanto, sendo o voto popular contrário à destituição, o presidente retornará, e a assembleia dissolverá” (MEDEIROS, 2002, p.221).

Portanto, a proposta de Medeiros compreende uma associação entre o presidencialismo e o parlamentarismo. Para o autor, o chefe de Estado é investido do poder moderador, através do voto popular a fim de representar a nação e resolver impasses distantes de facções e partidos (MEDEIROS, 2002). Aqui, não será adentrado no mérito acerca da competência ou não do Executivo para atuar como novo poder moderador. Todavia, detém o Judiciário tal prerrogativa?

\section{A ATUAÇÃO DO SUPREMO TRIBUNAL FEDERAL COMO PODER MODERADOR E SUAS CONSEQUÊNCIAS}

Sem muito esforço, nota-se que o papel de destaque alcançado pelo Poder Judiciário no contexto das vertentes hermenêuticas tem ultrapassado a perspectiva epistêmica. Sabe-se 
que no Brasil o Supremo Tribunal Federal acumula a dupla função de corte constitucional e instância recursal. E por isso, ao mesmo tempo que atua como órgão Político, integrado por ministros de "notável saber jurídico" e "ilibada reputação", nomeados pelo Presidente da República após aprovação pelo Senado Federal, atua também como órgão Judiciário.

Todavia, frequentemente o Supremo Tribunal Federal relativiza a separação dos Poderes, e atua diversas vezes como verdadeiro "Poder Moderador", argumentando estar suprindo eventuais falhas dos demais Poderes.

Percebe-se através das decisões cada vez mais “esdrúxulas" proferidas pelo STF, que sua atuação consiste em uma justiça - e não apenas jurisdição - constitucional, cujo volume de trabalho compromete suas decisões. Porém, mesmo dentro de sua atividade preponderante de jurisdição constitucional, o Supremo possui meios de intervenção nos demais Poderes:

\footnotetext{
Ao Supremo Tribunal Federal foram atribuídas funções que, na maioria das democracias contemporâneas, estão divididas em pelo menos três tipos de instituições: Tribunais constitucionais, foros judiciais especializados (ou simplesmente competências difusas pelo sistema Judiciário) e Tribunais de recursos de Última Instância. (Vieira, 2008, p.78).
}

Todavia, conforme esclarecido por Constant (2014), o Poder Moderador, na medida de sua função, teria o dever de trazer equilíbrio a sociedade através da preservação da soberania e da constituição.

\footnotetext{
Nenhuma autoridade sobre a Terra deve ter poderes ilimitados: a do povo; a dos homens representantes do povo; a dos reis, qualquer que seja o título como reinem; ou mesmo a da lei. Sendo a lei, a expressão da vontade do povo, ou do príncipe, segundo a forma de governo, deve circunscrever-se aos mesmos limites que os da autoridade da qual emana (CONSTATN, 2014. p.33).
}

Ou seja, Constant buscava a estrutura do equilíbrio entre os poderes sem que qualquer um dos deles tivesse poderes ilimitados, ou seja, a preservação dos poderes deveria se coadunar a manutenção da soberania, o que conferiu embasamento a criação da teoria dos cinco poderes constitucionais com fundamentação em um Poder Moderador, que a partir deste ponto iria se chamar "neutro, ou seja, não seria influenciável por qualquer outro dos poderes" (CONSTANT, 2005, p. 19). 
Destaca-se que a justificativa do poder moderador era a necessidade de preservar o sistema político em sua essência moderna e democrática, e isso coincidia com a finalidade de uma tradição política que justificava a supressão de determinada praxe ou de um conjunto de princípios, válidos na esfera individual, em nome da conservação do poder (FRELLER, 2014). Segundo Foucault:

Trata-se essencialmente, nessa razão de Estado, por essa razão de Estado, de identificar o que é necessário e suficiente para que o Estado exista e se mantenha em sua integridade, se preciso for, caso seja necessário e suficiente para restabelecer essa integridade, se ela vier a ser comprometida. Mas essa razão de Estado não é, de modo algum, um princípio de transformação, diria inclusive de evolução do Estado. Claro, vocês acharão a palavra —ampliação [...]. Mas essa ampliação nada mais é, no fundo, que a majoração, o aperfeiçoamento de um certo número de traços e de características que já constituem efetivamente o Estado e não é, de modo algum, a sua transformação. A razão de Estado é portanto conservadora (Foucault, 2008, p. 344).

Assim, à luz da ideia proposta por Benjamin Constant, Medeiros (2002) defende que também deveria haver no sistema republicano o caráter moderador na pessoa do presidente.

Se, no dizer de Benjamin Constant, a grande vantagem da monarquia constitucional foi ter criado esse poder neutro (moderador) na pessoa de um rei, por que não há de a República criar esse mesmo poder na pessoa do presidente? (MEDEIROS, 2002, p.75).

No entanto, o presidencialismo parlamentarizado de Borges de Medeiros se concentrava em combater o presidencialismo Imperial Brasileiro, uma vez que havia unificado a chefia de Estado e Governo. Victor José Faccioni, no prefácio do livro de Borges de Medeiros, assinala que para além das distorções do nosso regime presidencialista, "não há qualquer outra nação democrática que adote o Presidencialismo com o expediente da medida provisória ” (MEDEIROS, 2002, p.15), que faz por enfraquecer a democracia.

Fundir ou amalgamar as virtudes e utilidades dos dois sistemas contrários, e com esses elementos construir um novo tipo de presidencialismo [...] Eis o nosso principal objetivo e quiçá a maior originalidade deste projeto. Em nossa concepção, o rol do presidente consistirá em presidir a República como seu primeiro magistrado, e não como seu primeiro líder político. Fora da atmosfera dos partidos e posto na posição de livrar-se de qualquer influxo dos interesses e paixões do mundo 
político, há ele de reunir os predicados e requisitos que fazem o verdadeiro magistrado. (MEDEIROS, 2002, p.63).

Borges de Medeiros pretendeu reelaborar a aplicação do poder moderador desde o império, com o objetivo de reverter os efeitos deletérios daquele poder sobre o sistema de governo presidencialista. Assim, a obra O poder moderador na república presidencial, de 1933, procurou coadunar parlamentarismo e presidencialismo, influenciado pelo debate que já ocorria na época.

Art. 82 - O poder moderador é delegado privativamente ao presidente da República. O presidente é o supremo magistrado da nação, e o seu primeiro representante, a quem incumbe incessantemente velar sobre os destinos da República e sobre a conservação, equilíbrio e independência dos demais poderes políticos, assim como sobre a inviolabilidade dos direitos fundamentais. (MEDEIROS, 2002, p.116).

Medeiros destaca ainda que as atribuições fundamentais do poder moderador, deveriam ser delegadas "privativamente ao presidente da república". O autor levanta suspeitas quanto à legitimidade e à neutralidade de um presidente eleito por escolha indireta, resultante de combinações dentro da própria assembleia. Nesse sentido, sua origem democrática pelo povo é fundamental para o exercício das funções moderadoras. Assim, Borges de Medeiros destaca:

[...] se o presidente deve ser o chefe supremos do Estado, o primeiro representante da nação, é lógico e necessário que não seja ele uma criatura de nenhum desses poderes e sim uma emanação autêntica da soberania nacional, no seu livre e solene pronunciamento. A eleição direta é, pois, uma condição elementar a tão alta investidura, porque só o voto popular lhe poderá conferir com o caráter de principal mandato entre todos os mandatos, como deverá ser o do primeiro representante da nação. (MEDEIROS, 2002, p.64).

Boaventura de Souza Santos explica que a legitimidade ocupa lugar de destaque somente em regimes democráticos. Além disso, ela diz respeito a formação da vontade majoritária por meio das eleições. Por isso, nos países em que os membros do Poder Judiciário são indicados, ao invés de eleitos, torna-se natural que haja o questionamento do 
embasamento democrático do crescente intervencionismo deste poder nos demais poderes (SANTOS, 1996).

Dessa forma, chega-se à seguinte indagação: Se juízes e ministros não foram eleitos pela via democrática e não foram investidos pela vontade popular, e nem mesmo foram constituídos pela magna Carta detentores do poder de "moderar", uma vez que o Poder Moderador não se faz presente de forma clara e explícita na Constituição atual, com que embasamento atua o Supremo Tribunal Federal dessa forma?

Mister se faz explicitar que o principal limite imposto ao Poder Moderador era necessidade de garantir a separação dos poderes efetivamente, e ao contrário do que tende a ser, não virar uma espécie de Poder Absoluto. Todavia, o que se tem visto é que a atual inflação institucional do Poder Judiciário, mais especificamente do Supremo Tribunal Federal, desequilibrou a balança dos três poderes e possibilitou a consolidação de dois fenômenos que ditam o caminho político traçado pela sociedade brasileira, quais sejam, o ativismo judicial e a judicialização da política (LIMA, 2003).

Um dos exemplos claros acerca do fenômeno mencionado acima, encontra-se na decisão do Supremo Tribunal Federal, proferida em 2011, referente à Ação Direta de Inconstitucionalidade 4.277/2011, através da qual o STF reconheceu a constitucionalidade da união estável entre casais homo afetivos (BRASIL, 2011). Na argumentação da Corte Constitucional, foi defendida uma interpretação extensiva do artigo 226 da Constituição e uma interpretação conforme a Constituição do artigo 1.723 do Código Civil (BRASIL, 2002). Os sentidos conferidos aos termos "família", "homem" e "mulher" foram ampliados com vistas a conferir maior proteção a comunidade LGBTQ.

Assim, o Supremo Tribunal Federal, tomando como base apenas a vontade dos seus ministros (a decisão foi unânime) de promover uma transformação social pela via judicial, ultrapassou os limites semânticos impostos pelas normas constitucional e infraconstitucional, não obstante a inegável relevância da decisão em favor desse segmento social reconhecidamente marginalizado há décadas na sociedade brasileira.

Outro exemplo que merece atenção é a decisão do Supremo proferida no Habeas Corpus 152.752, na qual reconheceu a constitucionalidade da prisão do réu antes do trânsito em julgado do processo penal e, consequentemente, definiu uma política pública por meio do uso do controle de constitucionalidade, um instrumento jurídico de proteção dos direitos fundamentais (BRASIL, 2018). Em sua argumentação, o STF discutiu os limites do princípio 
da presunção de inocência e defendeu uma interpretação extensiva do inciso LVII do artigo $5^{\circ}$ da Constituição de 1988, visando supostamente combater do problema da impunidade no Brasil.

Ocorre que, inobstante o Supremo Tribunal Federal tenha direcionado a sua retórica para o debate de natureza jurídica, restou evidente que o seu objetivo principal era predominantemente político. O STF revestiu a sua vontade política de verdade científica com vistas a solucionar uma questão política, ultrapassando expressamente os limites jurídicos impostos pela Constituição Federal de 1988.

Ainda nesse sentido, merece atenção a recente decisão do Supremo. O Partido Trabalhista Brasileiro - PTB ajuizou uma Ação Direta de Inconstitucionalidade, $\mathrm{n}^{\circ}$. 6.524/2020, requerendo que fosse conferida "interpretação conforme à Constituição ao artigo $5^{\circ}$ e $\S 1^{\circ}$ do Regimento Interno da Câmara dos Deputados e ao artigo 59 do Regimento Interno do Senado Federal para que a vedação constitucional à reeleição ou recondução à Mesa na eleição imediatamente subsequente se aplicasse nas eleições que ocorresse na mesma legislatura ou em legislaturas diferentes, bem como que fosse afastada qualquer interpretação inconstitucional no intuito de ampliar o alcance do mencionado dispositivo constitucional (BRASIL, 2020).

O pedido foi fundamentado na intenção esdrúxula do Supremo em alterar a regra interna através de "mudança regimental, questão de ordem ou qualquer outro meio de fixação de entendimento próprio à atividade parlamentar", e não necessariamente pela aprovação de uma PEC (proposta de emenda à Constituição) " (MENDES, 2020).

Destaca-se que a Constituição Federal, no artigo 57, veda, expressamente, a reeleição para qualquer cargo na Mesa nas eleições imediatamente subsequentes àquela na qual o Deputado ou Senador foi eleito para a Mesa, ou seja, a regra constitucional é direta e objetiva. Todavia, um dos Ministros da Corte tentou alterar o entendimento literal da Constituição. Veja-se:

Ante o exposto, julgo parcialmente procedente o pedido formulado na ação direta para declarar, sem redução de texto, a inconstitucionalidade de interpretação dos dispositivos do art. 59 do RISF e do art. $5^{\circ}$, caput e $\S 1^{\circ}$, do RICD que acarrete imediata e genérica proibição de reeleição ou recondução sucessiva de Membro da Mesa para o mesmo cargo, permitindo-se, como direta decorrência do princípio da separação dos poderes e da cláusula constitucional da autonomia do Poder Legislativo (art. $2^{\circ}$, art. 51, III, IV e art. 52, XII e XIII, CF), que os Membros das respectivas Casas do Congresso Nacional tenham a prerrogativa de, em sede 
regimental, por questão de ordem ou mediante qualquer outro meio de fixação de entendimento próprio à atividade parlamentar, deliberar especificamente sobre a matéria, desde que observado, em qualquer caso, o limite de uma única reeleição ou recondução sucessiva ao mesmo cargo da Mesa, e assentando-se, outrossim, que o limite de uma única reeleição ou recondução, acima veiculado, deve orientar a formação das Mesas da Câmara dos Deputados e do Senado Federal a partir da próxima legislatura, resguardando-se, para aquela que se encontra em curso, a possibilidade de reeleição ou recondução, inclusive para o mesmo cargo (MENDES, 2020).

Conforme explicitado no voto de outro Ministro, não cabe ao Poder Judiciário funcionar como "atalho para a obtenção facilitada de providências perfeitamente alcançáveis no bojo do processo político-democrático, ainda mais quando, para tal mister, pretende-se desprestigiar a regra constitucional em vigor" (FUX, 2020). Em que pese a ADI ter sido julgada procedente, restou lamentável a proposta sugerida pelo Ministro Gilmar Mendes.

A vedação de recondução nas mesas diretoras, contida no artigo $57, \S 4^{\circ}$, da Constituição, poderia ser objeto de deliberação interna por meio de votação de proposta de emenda constitucional que revisitasse as regras aplicáveis. Essa medida, único meio adequado para contemplar as questões políticas que sublinham o caso, teria evitado a sua precoce judicialização, além de corroborar para a crescente hipertrofia do Judiciário, que ocorreu antes mesmo de formalizadas as candidaturas para a eleição vindoura.

A exacerbada Judicialização do Supremo concernente às questões políticas é umas das consequências de o Supremo Tribunal Federal agir como o "novo poder moderador". Assim como no caso do ativismo judicial, sabe-se que não há uma definição pacífica da judicialização da política na doutrina. Nessa perspectiva, Barroso delimita judicialização da política como a "resolução de controvérsias políticas pelo Poder Judiciário, não pelas instâncias tradicionais: os Poderes Executivo e Legislativo" (BARROSO, 2012, p. 24-28). Entretanto, o autor defende que diferentemente do ativismo judicial, a judicialização da política independe da vontade de qualquer juiz ou tribunal.

De acordo com Ran Hirschl (2006), a judicialização da política consiste na interferência de juízes e tribunais sobre impasses morais e políticos, e esse fenômeno se divide em três faces: a primeira (judicialização orgânica) manifesta-se pela "disseminação de discursos, jargões, mandamentos e procedimentos jurídicos na esfera política e nos fóruns decisórios dos impasses da vida cotidiana" (HIRSCHL, 2006, p. 723); a segunda (judicialização vinda de baixo) se manifesta pela “expansão de competência de juízes e 
tribunais para a definição de políticas públicas por meio do uso dos instrumentos jurídicos de proteção dos direitos fundamentais" (HIRSCHL, 2006, p. 724); e a terceira (judicialização da megapolítica) manifesta-se pelo julgamento, por juízes e tribunais, de controvérsias políticas centrais que definem e dividem comunidades inteiras (HIRSCHL, 2006, p. 727).

Com base nos exemplos citados, pode-se afirmar que a atuação política do Supremo Tribunal Federal ultrapassou os limites impostos pela Magna Carta de 1988 e adentrou a seara política da sociedade brasileira durante os últimos trinta e dois anos. Juízes e tribunais se valem do aparato institucional judicial para promover não apenas o bem-comum, mas também suas vontades pessoais, fazendo com que o pacto democrático, essencial para a manutenção da estrutura política brasileira, seja fragilizado, e consequentemente, o cumprimento das promessas constitucionais fica cada vez mais distante e improvável (BELO; BERCOVICI; LIMA, 2018).

A atual forma de agir do Poder Judiciário, mais especificamente, da Corte Suprema, tem se assemelhado às prerrogativas atribuídas ao Poder Moderador na Constituição Imperial de 1824. Assim como fazia o Imperador, juízes e tribunais afirmam estarem em um "patamar acima dos demais agentes políticos, e que por isso, suspostamente, possuem uma neutralidade ilusória" (MAUS, 2000, p. 183-202).

A soberania que deveria ser exercida pelo povo, passou a ser exercida pelo Supremo, e este passou a decidir as controvérsias políticas sociais, impedindo assim a participação política popular. Os Poderes Executivo e Legislativo encontram óbices a atuação de seus papéis, exatamente como acontecia na época do Poder Moderador no Brasil Império. No século XIX, essa instituição era a Coroa, representada pela figurada imperador; no século atual essa instituição é o Poder Judiciário, representado pelo Supremo Tribunal Federal.

Ocorre que no Brasil Império, buscava-se o controle e a limitação da soberania por meio da atuação do imperador, chefe dos Poderes Executivo e Moderador. Quando os demais poderes ultrapassavam as suas prerrogativas e adentrava na seara de incidência que não lhes pertencia, o Poder Moderador era invocado, e o Imperador aparelhava as instituições políticas para que funcionassem da forma prevista (MAUS, 2000). Porém, no Brasil redemocratizado, a soberania que deveria ser exercida pelo povo e pelos seus representantes, é ofuscada pelo Poder Judiciário que decide as principais controvérsias políticas e, consequentemente, impossibilita a real participação política popular. Os Poderes Executivo e Legislativo encontram-se inaptos de decidirem os rumos democráticos do País, uma vez que os "juízes e 
os tribunais atuam como o superego de uma sociedade infantilizada, que não tem a capacidade de autogerência” (MAUS, 2000, p. 198).

O Supremo tem usado a justificativa de atuação ativa para a manutenção do equilíbrio político e da unidade nacional para consolidar e ampliar cada vez mais o seu poder. O constitucionalismo brasileiro, moldado pela crença da necessidade de uma instituição capaz de controlar os anseios dos diversos agentes políticos, gerou uma inflação institucional do Poder Judiciário capaz de estabelecê-lo como um órgão político de caráter ilimitado e cada vez mais hipertrofiado. Ocorre que o poder real proposto por Constant que se transformou na lógica do Poder Moderador, e consequentemente se transformou na lógica da ampliação do Poder exercido pela Corte Suprema, não sustenta uma sociedade que pretende ser democrática e soberana. De forma similar à exercida pelo Imperador, juízes e tribunais afirmam encontrarse em um patamar superior aos demais agentes políticos.

Dessa forma, a excessiva judicialização de conflitos eminentemente políticos desqualifica os espaços de interlocução democrática e além disso instiga o Poder Judiciário, no caso em tela, o STF, a intervir em questões que poderiam ser solucionadas através dos mecanismos típicos do processo político-democrático, resultando em um "protagonismo danoso para a sustentabilidade do sistema constitucional” (BRASIL, 2020).

Portanto, faz-se necessário um remanejo de contenção do Poder Judiciário do STF, seja pelos poderes representativos da soberania popular, seja pela própria soberania popular, com fulcro na Magna Carta. Os limites a atuação do Supremo devem ser ancorados pelo próprio Supremo, uma vez que qualquer tentativa externa de controle será considerada interferência de um poder no outro.

\section{O CARÁTER POLÍTICO DO SUPREMO TRIBUNAL FEDERAL}

A discussão acerca do caráter político da Suprema Corte perdura desde a sua criação até os dias atuais. Em que pese sua descrição como órgão de cúpula do Poder Judiciário Brasileiro, prevalece uma atenção especial para as relações entre direito e política e a chamada politização da Corte Suprema. As críticas começam quando da compreensão do que deveria ser uma Corte no Estado de Direito, uma vez que decisões políticas o desviariam do seu papel, que o constitui como imparcial e neutro às decisões políticas, em regra. 
Para Niklas Luhmann (1996) a análise semântica da palavra ‘constituição’ revela a dualidade entre política e direito. "Constitutio podia expressar tanto um conceito político, no sentido de corpo do soberano, quanto um conceito jurídico, como decretos de direito positivo com força de lei” (LUHMANN, 1996, p. 85).

Após uma análise da história constitucional brasileira que ocorre na transição do Império para a República, percebe-se que o papel de guardião máximo da Constituição desloca-se do Poder Moderador para o Supremo Tribunal Federal, o que revela um problema fundamental para a aplicação do Direito, no que diz respeito a tensão entre, o que alguns autores chamam de "forma indisponível do Direito e decisão política" (REPOLÊS, 2008, p.27).

Conforme elucidado por Barbalho (1924) um dos sentidos conferidos ao termo 'político' foi o institucional. Nesse caso, o STF configuraria um terceiro poder capaz de equilibrar o poder Legislativo e Executivo bem como consolidar a República e a Democracia.

\begin{abstract}
A magistratura que agora se instala no país, graças ao regime republicano, não é um instrumento cego ou mero intérprete na execução dos actos do poder legislativo. Antes de aplicar a lei cabe-lhe o direito de exame, podendo dar-lhe ou recusar-lhe sanção, se ela lhe parecer conforme ou contraria à lei orgânica. (...)Aí está posta a profunda diversidade de índole que existe entre o Poder Judiciário, tal como se achava instituído no regime decaído, e aquele que agora se inaugura, calcado sobre os moldes democráticos do sistema federal. De poder subordinado, qual era, transforma-se em poder soberano, apto na elevada esfera da sua autoridade para interpor a benéfica influência do seu critério decisivo, a fim de manter o equilíbrio, a regularidade e a própria independência dos outros poderes, assegurando ao mesmo tempo o livre exercício dos direitos do cidadão" (BARBALHO, 1924)
\end{abstract}

Nesse viés, Dworkin (1999) explicou que o Poder Moderador ocupou o lugar deixado vazio pela tradicional autoridade no processo de secularização, aproveitando-se da ambiguidade simbólica da representação daquela figura. Assim, pode-se compreender que os limites instituídos no Império tornaram a criação do Supremo Tribunal Federal um acontecimento ainda mais original para a história, uma vez que a guarda da Constituição passou para as mãos de corpo técnico-jurídico e colegiado, tendo sua força normativa ampliada, por se transformar em "argumento para a resolução de conflitos políticos" (DWORKIN, 1999). 
Desse modo, o papel de guardião da Constituição pode ter a sua compreensão reformulada e nesse sentido, o STF tem a prerrogativa de afirmá-la como forma indisponível e como ponto de partida da ordem política e social, sem a qual, o exercício político se tornaria algo desregrado. A constituição deve ser colocada como limite e como condição de possibilidade, e a política, como dinâmica de consecução de fins racionais (REPOLÊS, 2008). Assim, em que pese o Poder Judiciário se transformar no grande arquiteto, capaz de "construir e reconstruir as práticas sociais instituídas por meio da interpretação de textos", essa construção e reconstrução não podem implicar na apropriação, seja por parte do Poder Judiciário, seja por parte do STF, dos "sentidos atribuídos às práticas sociais" (CARVALHO NETTO, 1999, p. 473-486).

Repolês (2008) afirma ainda que a partir da confirmação da hipótese de que não se pode fazer uma "Teoria da Constituição sem uma correlata Teoria de Direitos Fundamentais" (REPOLÊS, 2008, p. 101), torna-se possível reconstruir o papel político institucional do Supremo Tribunal Federal, que é o de garantidor de um "processo político democrático, cuja responsabilidade, como intérprete final da Constituição, é incorporar as diferenças através dos direitos fundamentais" (REPOLÊS, 2008, p. 101), permitindo que a democracia seja compreendida como processo de realização destes direitos e se baseie em uma soberania popular amplamente difusa.

Se tal hipótese se confirma, torna-se possível reconstruir o papel políticoinstitucional do Supremo Tribunal Federal, que é o de garantir um processo político democrático, possibilitando que a democracia seja compreendida como processo de concretização dos direitos fundamentais apoiado em uma soberania popular. Dessa forma, a decisão não será de um Ministro ou de outro, mas sim conforme o interesse da sociedade, e pautada na Constituição, a principal fonte principiológica de todo direito.

\section{CONSIDERAÇÕES FINAIS}

A hipótese de um poder "neutro" perpassa o questionamento feito pela Filosofia política desde muito tempo. De acordo com a teoria proposta por Benjamim Constant, a soberania não deveria ser ilimitada e deve ser restringida pelo poder real, com vistas a moderar os conflitos travados entre os demais poderes, e que deveria se concentrar em uma instituição política externa, neutra e reativa. 
O Supremo Tribunal Federal tem expandido sua competência e seus poderes para muito além do previsto na Magna Carta de 1988, ao decidirem controvérsias políticas com base na necessidade de concretização dos direitos e das garantias fundamentais, o que consequentemente, limita a participação política do povo e dos seus representantes, os verdadeiros soberanos, fragilizando assim o pacto democrático brasileiro. Demonstrou-se que a atuação da Corte como o novo poder moderador não condiz com o atual Estado Democrático de Direito.

De qualquer forma, se nenhum dos poderes se sobrepõe ao outro nas próprias prerrogativas legislativas, a reforma do sistema de governo seria crucial na tentativa de reformar o sistema para um sistema de maior responsabilidade política bem como para uma democracia representativa de fato. A melhor reforma sem dúvida seria objeto de discussão infindável, mas que certamente deve ter como norte a harmonia entre os poderes.

Viu-se que a crescente atuação política dos juízes e dos tribunais tem promovido uma inflação institucional do Poder Judiciário e derivado no ativismo judicial e na judicialização da política. Ao decidirem controvérsias políticas com base na necessidade de concretização dos direitos e das garantias fundamentais e também de promoção de um estado de bem-estar social, os juízes expandem as suas competências típicas e limitam a participação política do povo e dos seus representantes, que são os verdadeiros soberanos, fragilizando assim, o pacto democrático brasileiro.

Dessa forma, uma possível e aparentemente a única solução para a limitação do poder do Supremo Tribunal Federal não é a instituição de um novo poder mediador e nem a atuação deste como tal, (como, possivelmente, proporia Benjamin Constant), mas sim a concretização do sistema de freios e contrapesos, exercida pela própria Corte, bem como a promoção da participação política representativa e popular, vistas a delimitação do poder da Corte, pela própria Corte. 


\section{REFERÊNCIAS}

BARBALHO, João U.C, Constituição Federal Brasileira: comentários. 2 ed. correcta e argumentada pelo Autor. Rio de Janeiro: F. Briguiet e Cia. Editores, 1924.

BARROSO, Luís Roberto. Judicialização, ativismo judicial e legitimidade democrática. Rio de Janeiro, v. 5, n. 1, p. 23-32. 2012.

BELLO, Enzo; BERCOVICI, Gilberto. LIMA, Martonio Mont'Alverne Barreto. O Fim das Ilusões Constitucionais de 1988? Revista Direito e Práxis, Rio de Janeiro, 2018.

BESTER, Gisela Maria. Direito Constitucional. São Paulo: Manole, 2005.

BRASIL. Constituição Política do Império do Brasil, de 25 de março de 1824. Disponível em: http://www.planalto.gov.br/ccivil 03/Constituicao/Constituicao24.htm Acesso em: 5 set. 2020.

BRASIL. Lei $\mathbf{n}^{\mathbf{0}}$ 10.046, de 10 de janeiro de 2002. Institui o Código Civil. Brasília, DF: Presidência da 2002. Depública, Disponível em: http://www.planalto.gov.br/ccivil 03/leis/2002/110406.htm Acesso em: 2 out. 2020.

BRASIL. Supremo Tribunal Federal. Ação Direta de Inconstitucionalidade 4.277. Brasília, DF, 13 out. 2011. Disponível em: http://redir.stf.jus.br/paginadorpub/paginador.jsp?docTP=AC\&docID=628635 Acesso em:2 out 2020.

BRASIL. Supremo Tribunal Federal. Ação Direta de Inconstitucionalidade 6.524. Brasília, DF, 13 out. 2011. Disponível em: https://www.conjur.com.br/dl/voto-fux-reconducao-camarasenado.pdf Acesso em: $9 \mathrm{dez} 2020$.

BRASIL. Supremo Tribunal Federal. Ação Direta de Inconstitucionalidade 6.524. Brasília, DF, 13 out. 2011. Disponível em: http://portal.stf.jus.br/processos/detalhe.asp?incidente=5972250 Acesso em: 12 dez 2020 .

CAMPOS, Gabriel Afonso. Poder Neutro e razão de Estado em Benjamin Constant. Revista de Ciências do Estado. Belo Horizonte: v. 4, n. 1, 2019, e5150. ISSN: 2525-8036.

CARVALHO NETTO, Menelick de. Requisitos pragmáticos da interpretação jurídica sob o paradigma do Estado Democrático de Direito. In: Revista de Direito Comparado, Belo Horizonte, Mandamentos, vol. 3, p. 473-486, maio de 1999.

CONSTANT, Benjamin. Escritos políticos. $1^{\text {a }}$ Ed. São Paulo: Martins Fontes, 2005.

CONSTANT, Benjamin. Princípios políticos Constitucionais. $2{ }^{\text {a }}$ Ed. Rio de Janeiro: Freitas Bastos Editora, 2014, Pág. 33-34. 
DWORKIN, Ronald. O Império do Direito. Tradução de Jefferson Luiz Camargo. São Paulo: Martins Fontes, 1999.

FOUCAULT, Michel. Segurança, Território, População. Curso dado no College de France (1977-1978). Tradução de Eduardo Brandão. São Paulo: Martins Fontes, 2008.

FRELLER, Felipe. Madame de Stael, Benjamin Constant e a reavaliação do arbítrio após o golpe do 18 frutidor. Revista Brasileira de Ciências Sociais, v. 34, n. 100, 2019, p. e3410004. Disponível

https://www.academia.edu/38485088/Madame_de_Sta\%C3\%ABl_Benjamin_Constant_e_a_r eavalia\%C3\%A7\%C3\%A3o_do_arb\%C3\%ADtrio_ap\%C3\%B3s_o_golpe_do_18_Frutidor

Acesso em: 14 out. 2020.

HIRSCHL, Ran. The new constitutionalism and the judicialization of pure politics worldwide. Fordham Law Review, New York, v. 75, n. 2, p. 721-753, 2006. Disponível em: https://ir.lawnet.fordham.edu/cgi/viewcontent.cgi? referer $=\&$ httpsredir $=1$ \&article $=4205 \&$ cont ext=flr Acesso em: 16 ago. 2020.

LIMA, Martonio Mont'Alverne Barreto. Jurisdição Constitucional: Um Problema da Teoria da Democracia Política. In: SOUZA NETO, Cláudio Pereira de; BERCOVICI, Gilberto; MORAES FILHO, José Filomeno de; LIMA, Martonio Mont'Alverne Barreto. Teoria da Constituição: Estudos sobre o Lugar da Política no Direito Constitucional. Rio de Janeiro: Lumen Juris, 2003.p. 199-261.

LUHMANN Niklas. La Constituzione come acquisizione evolutiva. In: ZAGREBELSKI, Pier Paolo (org). Il Futuro dela Constituzione. Torino: Einaudi, 1996.

MAUS, Ingeborg. Judiciário como Superego da Sociedade: o papel da atividade jurisprudencial na "sociedade órfã". Novos Estudos CEBRAP, São Paulo, v. 58, p.183202,2000 .

MEDEIROS, B. de. O poder moderador na república presidencial. Caxias do Sul: EDUCS, 2002.

NUNES, Edson Correa. Ernest Hambloch e Borges de Medeiros: Presidencialismo e Poder Moderador no Brasil. Universidade Estadual Paulista. Faculdade de Ciências e Letras. São Paulo. Revista sem Aspas. v. 3, n. 1/2, jan./dez. 2014. Disponível em: https://periodicos.fclar.unesp.br/semaspas Acesso em: 8 set. 2020.

PAZZINATO, Alceu L.; SENISE, Maria Helena V. História moderna e contemporânea. 14. ed. São Paulo: Ática, 2002.

REOLÊS, Maria Fernanda Salcedo. Quem deve ser o guardião da constituição? Do poder moderador ao Supremo Tribunal Federal. Belo Horizonte. Mandamentos, 2008.

SANTOS, Boaventura de Souza. Os tribunais da sociedade contemporâneas: o caso português. 2 ed. Porto: Afrontamento, 1996. 
VIEIRA, Oscar Vilhena. Supremocracia. Revista Direito GV, São Paulo, 4(2), p. 441-464, jul./dez. 2008. Disponível em: http://www.scielo.br/pdf/rdgv/v4n2/a05v4n2.pdf Acesso em: 8 set. 2020. 